УДК $582.26 / .27 .084 / .085$

\author{
К.Б. Сардарян ${ }^{1}$, Т.М. Корня \\ ${ }^{1}$ Одеський національний університет імені I.I. Мечникова \\ вул. Дворянська, 2, Одеса, 65082, Україна, тел.: +38 (048) 6876 42, \\ e-mail: karinasardarian@gmail.com \\ 2 ТОВ «Науково-виробничий центр «ІН ВІТРО ПЛАНТ» \\ вул. Отамана Головатого 84а, Одеса, 65003, Україна, тел.:+38 (067) 4154 369, \\ e-mail: invitroklon@gmail.com

\section{ЕФЕКТИВНІСТЬ ВИКОРИСТАННЯ ЕКСТРАКТІВ ВОДОРОСТЕЙ В МІКРОКЛОНАЛЬНОМУ РОЗМНОЖЕННІ ДЕЯКИХ ВИДІВ РОСЛИН}

\begin{abstract}
Мета: дослідження розвитку експлантів деяких культурних рослин в умовах in vitro на МС середовищі з додаванням екстрактів водоростей. Матеріали та методи: в роботі використано стандартне живильне середовище Мурасіге та Скуга (1962) з половинним вмістом солей. В роботі застосовували декілька контрольних варіантів: 1) середовище МС без добавок; 2) з додаванням 0,1 мг/л штучних гормонів - БАП (бензинамінопурин); 3) 0,1 мг/л ГК (гіберелова кислота); 4) 0,1 мг/л IМК (індолілмасляна кислота) після автоклавування. В дослідних варіантах екстракти водоростей Ceramium virgatum Roth., Ulva intestinalis L., Cladophora vagabunda (L.) Hoek., Ulva compressa L. вносили в живильне середовище в конщентраціях 5 та 10\% (об/об) після його автоклавування. Ефект визначали за змінами ростових показників. Результати: досліджено водні екстракти деяких видів водоростей та їх біологічну активність. Визначено вплив екстрактів на розвиток експлантів деяких культурних рослин умовах in vitro. Показано, що сила та направленість змін, щзо викликані екстрактами, залежала від виду водоростей. $3 і$ збільшенням концентрації екстрактів деяких водоростей в живильному середовищі, спостерігали передозування мінеральними речовинами. Доцільним є використання екстрактів на рівні мікроелементів. Висновки: синтетичне живильне середовище може бути доповнене екстрактами водоростей, щзо сприятимуть збільшенню кількості експлантів (клонів).
\end{abstract}

Ключові слова: біологічно активні речовини, водорості, екстракт, ростові показники.

Однією 3 унікальних властивостей водоростей є склад їх біомаси і пластичність обміну речовин. Біомаса водоростей містить білок зі всіма незамінними амінокислотами, жирні кислоти, в тому числі $\omega^{3}$, вітаміни, мікроелементи, різноманітні специфічні біологічно активні речовини, серед яких: абсцизини, ауксини, цитокініни, гібереліни, етилен, поліаміни, брасиностероїди, жасмонат, саліцилати і олігоцукриди. На сьогодні у водоростях виявлені практично всі відомі фітогормони вищих рослин [4]. Досить тривалий час водорості використовувалися як джерело промислово важливих поліцукридів, таких як агар, карагінан, фукоїдан та ін. [3,7].

(C) К.Б. Сардарян ${ }^{1}$, Т.М. Корня ${ }^{2}, 2017$ 
Останнім часом збільшилася кількість досліджень, присвячених вивченню біологічно активних речовин екстрактів водоростей $[1,2]$.

Нами вже було проведено ряд досліджень, що підтверджують стимулювальний ефект екстрактів водоростей на деякі рослини, що вирощувалися in vivo $[5,6]$.

Метою роботи було дослідження розвитку експлантів деяких культурних рослин в умовах in vitro на середовищі Мурасіге та Скуга з додаванням екстрактів водоростей .

\section{Матеріали та методи}

В роботі використано стандартне живильне середовище Мурасіге та Скуга (MC) [9] з половинним вмістом солей. Для виявлення різної природи біологічно активних речовин водоростевих екстрактів в роботі застосовували декілька контрольних варіантів: 1) загальний контроль на виявлення біологічно активних речовин в екстрактах водоростей - стандартне середовище МС без додавань; 2) середовище $\mathrm{MC}$ з додаванням 0,1 мг/л штучного гормону бензинамінопурину (БАП) - для виявлення цитокінінової активності; 3) середовище МС 3 додаванням 0,1 мг/л індолілмасляної кислоти (IMК) - контроль ауксинової активності; 4) середовище МС з додаванням 0,1 мг/л гіберелової кислоти (ГК) - контроль гіберелінової активності.

Водорості, що були зібрані в Одеській затоці Чорного моря в жовтні 2016 р., відносяться до так званої групи ефемероїдів, тобто таких, що вегетують протягом усього року, утворюючи декілька поколінь.

В дослідних варіантах екстракти водоростей Ceramium virgatum, Ulva compressa, U. intestinalis і Cladophora vagabunda вносили в живильне середовище в концентраціях 5 та 10\% (об/об) після його автоклавування. Варіанти 3 екстрактами водоростей були моновидовими.

Екстракти водоростей отримували шляхом дрібнофракційного подрібнення їх фітомаси (5-10 г) з додаванням дистильованої води (100 мл). Потім з подальшою фільтрацією суспензії та холодною стерилізацією екстракту фільтруванням через фільтр Millipore з розміром пор 0,22 мкм. Всі отримані екстракти водоростей додавали до живильного середовища після його автоклавування та охолодження до температури $45^{\circ} \mathrm{C}$.

Для мікроклонування і подальшого вирощування на живильному середовищі використовували рослини з різними потребами до його складу, а саме: Ожина садова (Eubatus sp.) - невибаглива до мінерального складу; Орхідея декоративна (Dendrobium sp.) - епіфіт, що вимагає мінімальної кількості мінеральних речовин; Венерина мухоловка (Dionaea muscipula J. Ellis) комахоїдна рослина, яка нестачу азотних речовин компенсує за рахунок білка комах.

Типи експлантів дослідних рослин представляли собою органи та частини органів (для ожини - сегменти пагону, для мухоловки та орхідеї - регенеранти, отримані з калюсу) ізольовані від стерильної рослини.

Культивування експлантів рослин і постановку дослідів виконували в лабораторії мікроклонального розмноження «ІН ВІТРО ПЛАНТ».

Рослини вирощували при температурі $24{ }^{\circ} \mathrm{C}$ за світлового режиму $1 / 16$ годин. 3 метою виявлення впливу екстрактів водоростей на досліджувані 
об'єкти одноразово знімали ростові показники у мікророслин через однаковий проміжок часу культивування для всіх видів рослин - 28 діб, коли було отримано повністю сформовані рослини, готові до адаптації в грунті.

Ефект дії екстрактів водоростей оцінювали: для Ожини садової Eubatus sp. за середньою кількістю сформованих корінців, їх довжиною, площею листової пластинки і числом міжвузлів; у Орхідеї Dendrobium sp. - за середньою кількістю сформованих мікророслин і площею листової пластинки; для Мухоловки Dionaea muscipula - за загальною площею листової поверхні.

В дослідженні використовували метод багатофакторного дисперсійного аналізу ANOVA для вибірок з нормальним розподілом, а також метод порівняння груп за довірчим інтервалом.

\section{Результати дослідження та їх обговорення}

Найбільш високі показники середньої кількості міжвузлів спостерігали при вирощуванні мікророслин ожини на живильному середовищі $з$ екстрактом $C$. virgatum в концентрації $10 \%$ (рис. 1). Цей показник був подібним до варіанту середовища 3 цитокініном (БАП), що, можливо, пов'язано з високим вмістом даної групи фітогормонів в екстракті $C$. virgatum.

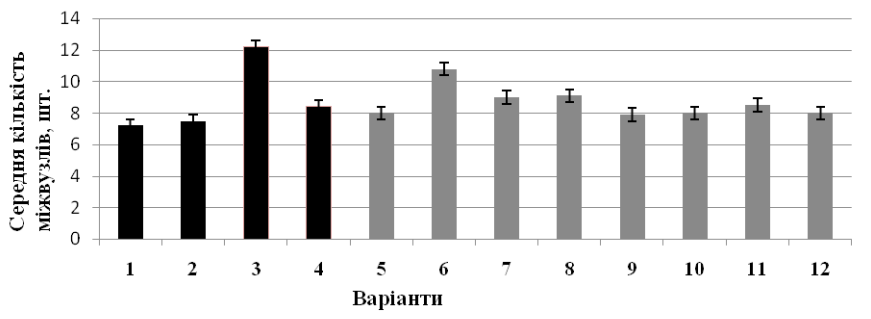

Рис. 1. Середня кількість міжвузлів мікророслин ожини.

Примітка (тут і на рис. 2-6): 1 - контроль (стандартне середовище МС без додавань), 2 - середовище МС 3 додаванням 0,1 мг/л штучного гормону БАП, 3 - середовище МС 3 додаванням 0,1 мг/л IMК, 4 - середовище МС 3 додаванням 0,1 мг/л ГК, 5 - середовище МC 3 додаванням 5\% екстракту C. virgatum, 6 - середовище МС 3 додаванням 10\% екстракту C. virgatum, 7 - середовище MC 3 додаванням 5\% екстракту U. intestinalis, 8 - середовище МС 3 додаванням 10\% екстракту U. intestinalis, 9 - середовище МС 3 додаванням 5\% екстракту C. vagabunda, 10 - середовище МС 3 додаванням $10 \%$ екстракту C. vagabunda, 11 - середовище MC 3 додаванням 5\% екстракту U. compressa, 12 - середовище МС 3 додаванням $10 \%$ екстракту U. compressa.

Fig. 1. The average number of blackberry micro plants inter-nodes.

Note (here and in fig.2-6): 1 - control (standard MS medium without additions), 2 - MS medium with the addition of $0.1 \mathrm{mg} / \mathrm{L}$ artificial hormone BAP, 3 - medium MS with the addition of $0.1 \mathrm{mg} / \mathrm{lMC}, 4-\mathrm{MS}$ medium with the addition of $0.1 \mathrm{mg} / \mathrm{l} \mathrm{CC}, 5-\mathrm{MS}$ medium with the addition of $5 \%$ extract of $C$. virgatum, 6 - MS medium supplemented with $10 \%$ extract of C. virgatum, 7 - MS medium with the addition of $5 \%$ extract of $U$. intestinalis, 8 - MS medium supplemented with $10 \%$ extract of U. intestinalis, 9 - MS medium with the addition of $5 \%$ extract of $C$. vagabunda, 10 - MS medium supplemented with $10 \%$ extract of $C$. vagabunda, 11 - MS medium with the addition of $5 \%$ extract $U$. compressa, 12 - MS medium supplemented with $10 \%$ extract $U$. compressa. 
Порівняно з стандартним середовищем, кількість міжвузлів збільшилася на $50 \%(\mathrm{P} \leq 0,05)$, що можна пояснити збільшенням кількості пагонів. Отримані дані показують, що даний екстракт можна використовувати на етапі мікроклонування ожини для збільшення кількісного виходу мікророслин.

Встановлено, що максимальною кількість корінців мікророслин ожини була у варіанті з екстрактом U. intestinalis в концентрації 10\% (рис. 2). Порівняно з контролем (середовище МС без добавок) цей показник був вищим на $48 \%(\mathrm{P} \leq 0,05)$. Ефект був подібним до варіанту досліду з ІМК. Тому, очевидно, даний екстракт може бути використаний на етапі вкорінення мікророслин ожини. В той же час $10 \%$ екстракт з C. vagabunda пригнічував ріст кореневої системи мікророслин.

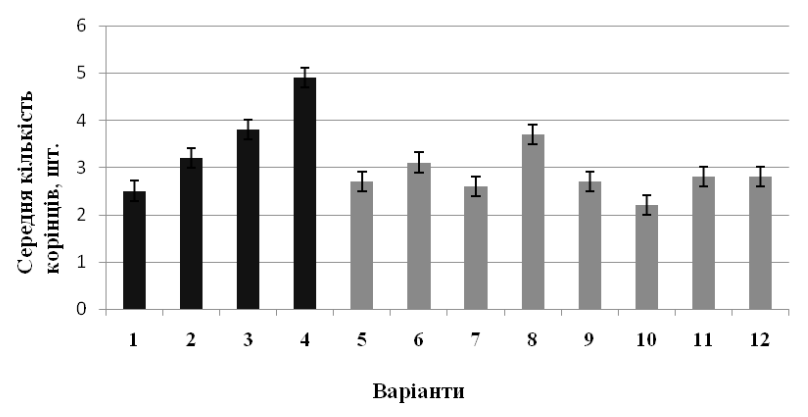

Рис. 2. Середня кількість корінців мікророслин Eubatus Natchez

Fig. 2. The average number of micro plants Eubatus Natchez roots

3 додаванням екстрактів водоростей U. compressa (концентрація 10\%, C. vagabunda (5\%), C. virgatum (5\% та 10\%) спостерігався інтенсивний ріст та галуження кореневої системи мікророслин ожини, що значно перевищували показники контрольних рослин (середовище МС без добавок) на 39,0\%, $34,5 \%, 32,0 \%, 37,0 \%(\mathrm{P} \leq 0,05)$, відповідно (рис. 3). Це може бути пов'язане 3 оптимальним вмістом поживних речовин в екстрактах, що сприяють нормальному росту та розвитку мікророслин.

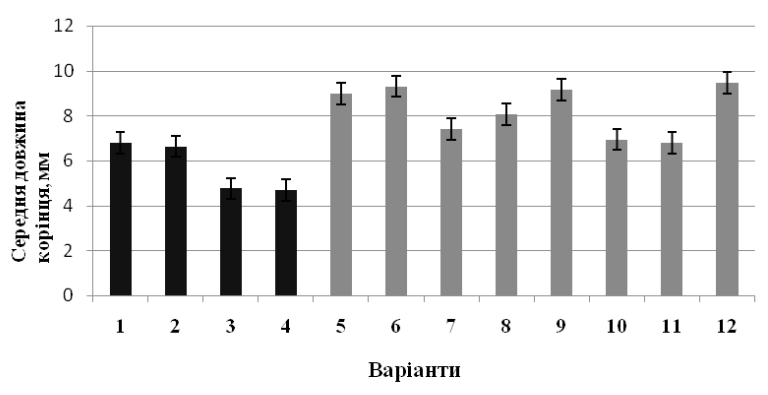

Рис. 3. Середня довжина корінців Eubatus Natchez

Fig.3. The average length of Eubatus Natchez roots 
У плотоядної мухоловки за дії екстракту $C$. vagabunda за концентрації 5\% було виявлено помітне збільшення листової поверхні (рис. 4). Цей показник значно перевищував такий у контрольному варіанті (середовище МС без добавок) на $77,4 \%(\mathrm{P} \leq 0,05)$. Оскільки збільшення пасток мухоловки в природі відбувається переважно за рахунок білкового живлення комахами, то можна припустити, що даний екстракт має кормовий білок. Отже, він може бути використаний для прискореного нарощування розмірів плотоядних мікророслин в штучних умовах культивування на етапі підготовки до адаптації в грунті.

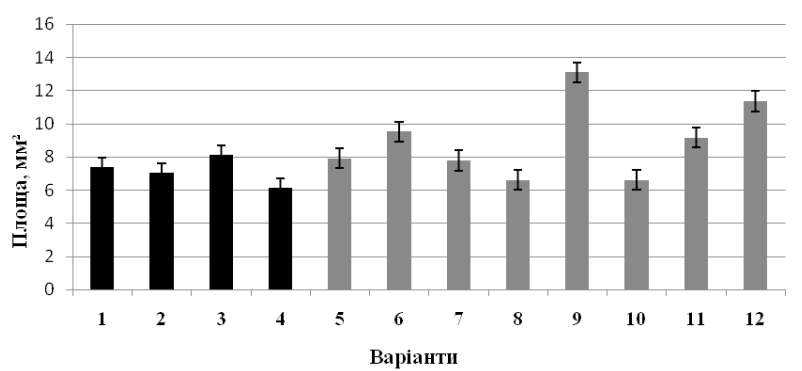

Рис. 4. Площа листової поверхні Dionaea muscipula

Fig. 4. The average leaf area of Dionaea muscipula

Площа листової пластинки орхідеї збільшувалася при вирощувані мікророслин на екстракті $C$. virgatum за концентрації 5\% порівняно з контролем (середовище МС без добавок) на 47\% (P $\leq 0,05)$ (рис.5). В той же час пригнічувальний вплив на збільшення площі листової пластинки мав 5\% екстракт U. intestinalis.

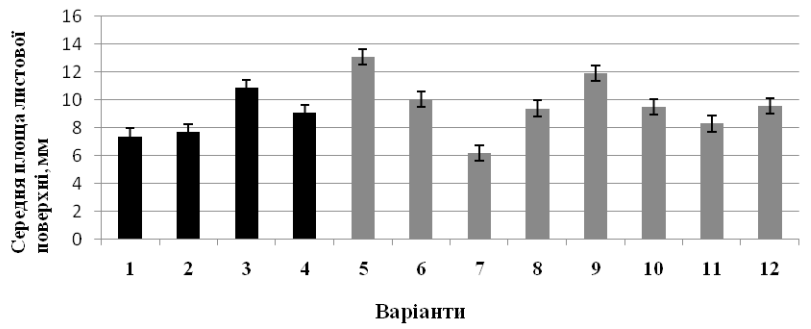

Рис. 5. Середня площа листової пластинки Dendrobium sp.

Fig. 5. The leaf area of Dendrobium sp.

Ефективність мікроклонального розмноження орхідеї є досить високою у варіантах з 10\% екстрактом C. vagabunda і сягає $177 \%$, a $U$. compressa $123 \%$, $35 \%$ екстрактом $U$. compressa - 97\%, a C. vagabunda $-46 \%(\mathrm{P} \leq 0,05)$ порівняно з контролем без добавок (рис. 6). Зважаючи на те, що БАП та ІМК у певних співвідношеннях впливають на збільшення кількості сформованих мікророслин, можемо зробити висновок, що у складі зазначених екстрактів $\epsilon$ достатня кількість гормонів ауксинового та цитокінінового ряду. Отже, використання даних екстрактів за правильно підібраної концентрації може збільшити кількість експлантів (клонів). Найменша кількість клонів спостерігалася за дії 5 та $10 \%$ екстракту U. intestinalis. 


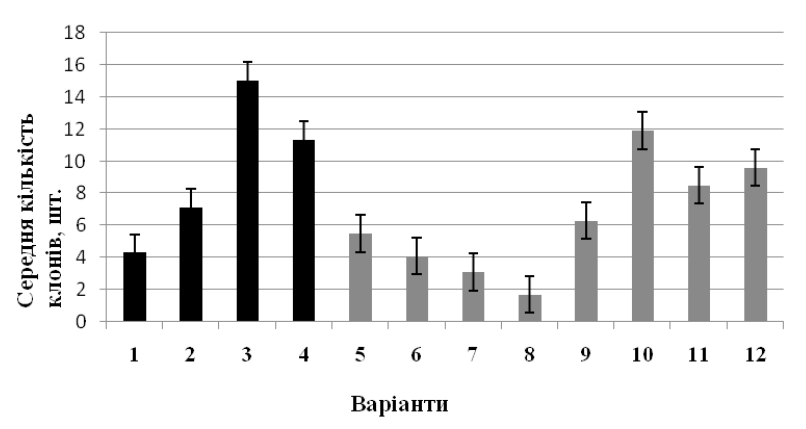

Рис. 6. Середня кількість сформованих мікророслин Dendrobium sp.

Fig. 6. The average number of formed micro plants Dendrobium sp.

У деяких дослідних варіантах при подальшому культивуванні орхідеї за вказаних концентрацій екстрактів водоростей спостерігали пригнічення росту рослин. Це проявлялося зміною кольору листя - від зеленого до жовто-зеленого, появою некротичних плям, а в деяких випадках відбувався і їх повний лізис. Це, очевидно, пов'язано з деяким передозуванням мінеральними речовинами, що містилися в екстрактах водоростей. Тому, доцільним для росту експлантів орхідей було використання екстрактів водоростей із зменшеною в 10 разів концентрацією.

Ефективність дії водоростевих екстрактів і його направленість повною мірою залежали від виду водоростей, що використовувалася для приготування витяжки. Ряд екстрактів чинили стимулювальну дію на певні етапи розвитку рослин, але деякі мали і пригнічувальний вплив.

Отже, синтетичне живильне середовище може бути доповнене екстрактами водоростей, оскільки останні мають позитивний ефект в культурі in vitro, можливо саме через унікальний склад макро- та мікроелементів, вітамінів та гормонів, частина 3 яких спричиняє вплив, подібний до впливу похідних від синтетичних гормонів.

Дякуємо за ідею та допомогу у виконанні досліджень у роботі проф. Ткаченку Ф.П.

\author{
K.B. Sardarian', T.M.Kornia ${ }^{2}$ \\ ${ }^{1}$ I.I. MechnykovOdesa National University, \\ 2, Dvoryanska St., Odesa, 65082, Ukraine, tel.: +38 (098) 21096 50, \\ e-mail: karinasardarian@gmail.com \\ ${ }^{2}$ LTD. "The Scientific and production center of "IN VITRO PLANT" \\ 84a, OtamanaHolovatoho St., Odesa, 65003, Ukraine, tel.:+38 (067)4154369, \\ e-mail:invitroklon@gmail.com
}

\title{
THE EFFICIENCY OF USING ALGA EXTRACTS IN THE MICROCLONAL REPRODUCTION OF SOME PLANT SPECIES
}

\author{
Summary \\ Aim: to study the development of explants of some cultivated plants in vitro \\ conditions using MC medium with addition of algae extracts.
}


Materials and methods: the standard Murashige and Skoog nutrient medium (1962) with a half content of salts was used in our work. There were used several control options: 1) MC medium without additives; 2) medium with addition of $0.1 \mathrm{mg} / \mathrm{l}$ of artificial hormones - BAP (benzylaminopurine); 3) $0.1 \mathrm{mg} / \mathrm{l} \mathrm{GA}$ (gibberelic acid); 4) $0.1 \mathrm{mg} / \mathrm{l}$ of IBA (indolylbutyric acid) after autoclaving. In the experimental variants, algae CeramiumvirgatumRoth., Ulvaintestinalis L., Cladophoravagabunda (L.) Hoek., Ulvacompressa L. were introduced into a nutrient medium in 5 and $10 \%(\mathrm{~V} / \mathrm{V})$ concentrationsafter its autoclaving. The effect was determined by the change of the growth indicators. Results: water extracts of some species of algae and their biological activitywere studied. The impact of extracts on the development of explants of some cultivated plants in vitro conditions was determined. It was shown that the strength and direction of changescaused by the extracts depended on algae species. The overdose with mineral substances was observedwith the increase of concentration of some algae extracts in nutrient medium. It is reasonable to use extracts at the level of microelements. Conclusions: synthetic nutrient medium can be supplemented with algae extracts, it will cause increasing of the quantity of explants (clones).

Key words: biologically active substances, algae, extract, growth indicators.

\section{К.Б. Сардарян ${ }^{1}$, Т.М. Корня ${ }^{2}$}

${ }^{1}$ Одесский национальный университет имени И.И. Мечникова ул. Дворянская, 2, Одесса, 65082, Украина, тел.: +38 (048) 6876 42, e-mail: karinasardarian@gmail.com

${ }^{2} \mathrm{OОО}$ «Научно-производственный центр« ИН ВИТРО ПЛАНТ » ул. Атамана Головатого 84a, Одесса, 65003, Украина, тел.: + 38 (067) 4154369 , e-mail: invitroklon@gmail.com

\section{ЭФФЕКТИВНОСТЬ ИСПОЛЬЗОВАНИЯ ЭКСТРАК- ТОВ ВОДОРОСЛЕЙ В МИКРОКЛОНАЛЬНОМ РАЗ- МНОЖЕНИИ НЕКОТОРЫХ ВИДОВ РАСТЕНИЙ}

\section{Реферат}

Цель: исследование развития эксплантов некоторых культурных растений в условиях in vitro на среде Мурасиге и Скуга (1962) с добавлением экстрактов водорослей. Материалы и методы: в работе использована стандартная питательная среда Мурасиге и Скуга (MC) с половинным содержанием солей. Для сравнения применяли несколько контрольных вариантов: среда МС без добавок; с добавлением 0,1 мг/л искусственных гормонов - БАП (бензинаминопурин) 0,1 мг/л ГК (гибберелловая кислота), 0,1 мг/л ИМК (индолилмасляная кислота) после автоклавирования. В опытных вариантах экстракты водорослей Ceramium virgatum Roth., Ulva intestinalis L., Cladophora vagabunda (L.) Hoek., Ulva compressa L. вносили в питательную среду в кониентрациях 5 и 10\% (об/об) после его автоклавирования. Эффективность экстрактов водорослей определяли по изменениям ростовых показателей в испьтуемых растениях. Результаты: исследованы водные экстракты некоторых видов водорослей и их биологическая активность. Определено влияние экстрактов на развитие эксплантов некоторых культурных растений условиях in vitro. Показано, что стимулирующая эффективность и ее направленность, вызванные экстрактами, зависели от вида водорослей. 
С увеличением концентрации экстрактов некоторых водорослей в питательной среде, наблюдали передозировки минеральными веществами. Поэтому ичелесообразно их использование с концентраџией не более 5\%. Выводы: синтетическая питательная среда может быть дополнена экстрактами водорослей, которые способствуют увеличению количества эксплантов (клонов).

Ключевые слова: биологически активные вещуества, водоросли, экстракты, ростовые показатели.

\section{СПИСОК ВИКОРИСТАНОЇ ЛІТЕРАТУРИ}

1. Тараховская Е.Р., Маслов Ю.И., Шишова М.Ф. Фитогормоны водорослей // Физиология растений. -2007. - 54, № 2. - С. 1-9.

2. Сиренко Л.А., Козицкая В.Н. Биологически активные вещества водорослей и качество воды. - К.: Наук. думка, 1988. - 256 с.

3. Гуд М. Дж.П., Сешикала Д., Сингара Чаря М.А. Антибактериальная активность и биохимический состав некоторых пресноводных водорослей реки Годовари (Индия) // Альгология. - 2008. - Т. 18, № 1. - С. 21-28.

4. Мусатенко Л.И. Рост и гормональный комплекс водорослей-макрофитов // Альгология. - 1999. - Т. 9, № 2. - С. 97-98.

5. Ткаченко Ф.П., Топтиков В.А. Экстракты морских водорослей как стимуляторы начальных этапов развития растений ячменя // Вісник Харківського нац. ун-ту імені В.Н. Каразіна. Серія: біологія». - 2008. - Вип. 7, № 814. - C. 199-204.

6. Ткаченко Ф.П., Сардарян К.Б. Влияние водорослевых экстрактов на начальные этапы развития Calendula officinalis // Міжнародна науково-практична конференція «Наука на службі сільського господарства ». - Миколаїв, 2013. - C. $185-186$.

7. Сардарян К.Б., Чернякевич С.С. Формування розсади томатів за передпосівної обробки їх насіння екстрактами водоростей-макрофітів // VI Відкритий з'їзд фітобіологів Причорномор'я (Херсон-Лазурне, 19 травня 2015. - Херсон, 2015. - С. 67.

8. Шаларь В.В., Шаларь В.М., Маня Ш. Применение синезеленых водорослей в качестве стимулятора роста культурных растений // Мат. III Междунар. конф. «Актуальные проблемы современной альгологии».- Харьков: ХHУ, 2005. - C. 179-180.

9. Murashige T., Skoog F. A revised medium for rapid growth and bioassays with tobacco cultures. Physiol. Plant., 1962. - 15 (3). - p. 473-497.

\section{References}

1. Tarakhovskaya ER, Maslov YI, Shishova MF. Algae phytohormones. Plants Physiology.2007; 54( 2):1-9.

2. Sirenko LA, Kasicka VN. Biological active substances of algae and water quality. Kiev.: Naukova Dumka, 1988: 256.

3. Hood MJ., Sasikala D, Singhara of Char MA. Antibacterial activity and biochemical composition some freshwater algae of the river Godavari (India). Algologia.2008; 18 (1):21-28. 
4. Musatenko LI. Growth and hormonal complex of algae-macrophytes Algologia.1999; 9( 2):97-98.

5. Tkachenko FP, Toptikov VA. Marine algae extracts as stimulators of the initial stages of development barley plants. The Jornal of V.N. Karazin Kharkiv National University. Series: «Biology».2008; 7(814):199-204.

6. Tkachenko FP, Sardaryan KB. The influence of algal extracts to initial stages the growth Calendula officinalis. International scientific-practical conference "Science for agriculture ", Nikolaev. 2013:185 - 186.

7. Sardaryan KB, Chernjakevich SS. Formation of tomato seedlings for pre-treatment of their seeds extracts of seaweeds. VI Congress of phytobiologic, Kherson. 2015: 67.

8. Şalari VV, Şalari VM, Manya S. The using of blue-green algae as a stimulant of growth cultural plants. Mat. III Intern. Conf. "Actual problems of modern Algology".Kharkiv: KhNU, 2005: 179-180.

9. Murashige T.,Skoog F. A revised medium for rapid growth and bioassays with tobacco cultures. Physiol. Plant., 1962; 15 (3) :473-497.

Стаття надійшла до редакції 10.04.2017 p. 